\title{
Leaf anatomy of six species of Heliotropiaceae Schrad. from the Brazilian semi-arid region
}

\author{
Elisabeth Emília Augusta Dantas Tölke * \\ Sandra Maria Carmello-Guerreiro \\ José Iranildo Miranda de Melo \\ ${ }^{1}$ Department of Plant Biology, Programa de Pós-Graduação em Biologia Vegetal \\ Institute of Biology, PO Box 6109, State University of Campinas \\ CEP 13083-970, Campinas - SP, Brazil \\ ${ }^{2}$ Center of Biological Sciences and Health, Department of Biology \\ State University of Paraíba, I Campus, CEP 58429-500, Campina Grande - PB, Brazil \\ * Author for correspondence \\ elisabeth.tolke@gmail.com
}

Submetido em 12/08/2014 Aceito para publicação em 19/06/2015

\section{Resumo}

Anatomia foliar de seis espécies de Heliotropiaceae Schrad. da região semiárida do Brasil. A família Heliotropiaceae possui mais de 450 especies distribuídas principalmente nas regiões tropicais e subtropicais. No Brasil está representada pelos gêneros Euploca Nutt., Heliotropium L., Myriopus Small e Tournefortia L. O objetivo do presente trabalho é descrever a anatomia foliar de seis espécies de Heliotropiaceae da região semiárida do Brasil: E. polyphylla (Lehm.) J.I.M. Melo \& Semir, E. procumbens (Mill.) Diane \& Hilger, H. angiospermum Murray, H. curassavicum L., M. rubicundus (Salzm. ex DC.) Luebert e M. salzmannii (DC.) Diane \& Hilger. Além de contribuir para o conhecimento da anatomia de representantes da família na Caatinga (Savana brasileira), este trabalho busca elencar e destacar características anatômicas adaptativas à região, bem como buscar caracteres com potencial valor diagnóstico. Foram realizados procedimentos usuais em Microscopia Óptica (MO) e Microscopia Eletrônica de Varredura (MEV). Também foram realizados testes adicionais para detectar a presença de amido e de lipídios totais. A variação morfológica e a distribuição dos tricomas foram as características mais relevantes no diagnóstico das espécies. A distribuição dos estômatos em M. salzmannii e $H$. angiospermum é distinta das descrições apresentadas em outros trabalhos, o que demonstra plasticidade anatômica nestas espécies. A anatomia foliar de M. rubicundus é descrita pela primeira vez neste trabalho.

Palavras-chave: Euploca; Heliotropium; Myriopus; Tournefortia; Tricomas

\section{Abstract}

The family Heliotropiaceae has more than 450 species, mainly distributed in the tropics and subtropics. In Brazil, it is represented by the genera Euploca Nutt., Heliotropium L., Myriopus Small and Tournefortia L. The aim of this study was to describe the leaf anatomy of six species of Heliotropiaceae recorded in the semiarid region of Brazil: E. polyphylla (Lehm.) J.I.M. Melo \& Semir, E. procumbens (Mill.) Diane \& Hilger, $H$. angiospermum Murray, H. curassavicum L., M. rubicundus (Salzm. ex DC.) Luebert and M. salzmannii (DC.) Diane \& Hilger. Besides contributing to the knowledge of the anatomy of the representatives of the family in 
the Caatinga (Brazilian savannah), we also sought to determine and highlight the anatomical features adaptive to the region and to identify features with potential diagnostic value. Leaf structures were analyzed by light microscopy and scanning electron microscopy. Additional tests were also carried out to detect starch and total lipids. The morphological variation and the distribution of trichomes were the most relevant features for species diagnosis. The distribution of stomata in M. salzmannii and H. angiospermum differed from that described in other papers, which demonstrates the anatomical plasticity of these species. This is the first report describing the leaf blade of $M$. rubicundus.

Key words: Euploca; Heliotropium; Myriopus; Tournefortia; Trichomes

\section{Introduction}

The family Heliotropiaceae is mainly distributed in the tropics and subtropics and comprises five genera and approximately 450 species (DIANE et al., 2002; 2003; GOTTSCHLING et al., 2004; LUEBERT et al., 2011). In Brazil, it is represented by the four genera Euploca Nutt., Heliotropium L., Tournefortia L. and Myriopus Small (MELO et al., 2009).

Tournefortia comprises approximately 150 species distributed in the Neotropics. Its representatives are allocated into two sections: Tournefortia sect. Tournefortia I.M. Johnst., with straight embryo and slightly lobed fruits; and T. sect. Cyphocyema I.M. Johnst., with curved embryo and a four-lobed fruit (CAVALHEIRO et al., 2011). In Brazil, both sections are represented by approximately 25 species (MELO et al., 2009). The inclusion of all species of $T$. sect. Cyphocyema in the genus Myriopus has been suggested by phylogenetic studies combined with morphological data, showing $T$. sect. Tournefortia as a polyphyletic group (DIANE et al., 2002). The species chosen for this study are in the genus Myriopus.

Euploca has approximately 50 species distributed in tropical, subtropical and temperate regions with centers of diversity in Africa, Australia and tropical America, especially in South America and Mexico. Its representatives are predominantly herbaceous, subshrubs and rarely shrubby (MELO; SEMIR, 2010). In Brazil, it is represented by 17 species (MELO et al., 2009).

The genus Heliotropium includes approximately 300 species, distributed in tropical and subtropical regions around the world (DIANE et al., 2004; IBÁÑEZ et al., 2011). It includes herbaceous, subshrubs, and more rarely, shrub representatives, where they are mostly characterized by scorpioid inflorescences, free stamens, and schizocarp fruit with two locules and two seeds (MELO; SEMIR, 2008). In Brazil, the genus is found along the coast (Restinga and Atlantic Forest formations) and on rocky outcrops and is widespread in the Cerrado as well as Caatinga (Brazilian savannah) and Pampas (Brazilian grassland) (MELO; SEMIR, 2008). Heliotropium comprises nine species (MELO et al., 2009).

Anatomical features have been used in taxonomic and phylogenetic analysis of Heliotropiaceae, but few representatives of the Brazilian flora, particularly from the Caatinga, have been included (DIANE et al., 2003; FARIÑA et al., 2003; MUHAIDAT et al., 2011). In the Caatinga, studies on Heliotropiaceae are limited to taxonomic aspects (MELO; SALES, 2005; MELO; ANDRADE, 2007; VIEIRA et al., 2013).

This study aimed to describe the leaf anatomy of six species of Heliotropiaceae found in the Brazilian semi-arid region, Caatinga biome: Euploca polyphylla, E. procumbens, Heliotropium angiospermum, $H$. curassavicum, Myriopus rubicundus and M. salzmannii. Besides contributing to the anatomical knowledge of the representatives of Heliotropiaceae in the Caatinga, we sought to determine and highlight the anatomical features adaptive to the semi-arid region, looking for characters with potential diagnostic value.

\section{Material and Methods}

Samples were collected in Caatinga areas in the states of Paraíba and Rio Grande do Norte, Northeastern Brazil: E. polyphylla. BRAZIL. Rio Grande do Norte. Porto do Mangue, 13-V-2007 (fl, fr), Melo et al. 610 
(MOSS). E. procumbens. BRAZIL. Rio Grande do Norte. Tenente Laurentino da Cruz, 66'45.3"S, 36'42'10.7'W, 09-IV-2004 (fl, fr), Melo \& Xavier 449 (MOSS, PEUFR). H. angiospermum. BRAZIL. Rio Grande do Norte. Florânia, 607'32.8'S, 3646'36.7'W, 09-IV-2004 (fl, fr), Melo \& Xavier 446 (MOSS, PEUFR). H. curassavicum. BRAZIL. Paraíba. Soledade, City's water reservoir, 17-IV-2009, Tölke 51 (ACAM). M. rubicundus. BRAZIL. Rio Grande do Norte. Serra Negra do Norte, Seridó Ecological Station, 20-IV-2007 (fl, fr), Melo et al. 594 (MOSS). M. salzmannii. BRAZIL. Rio Grande do Norte. Patu, Serra do Lima, 30-I-2008, Melo et al. 661 (MOSS).

Three fully expanded leaves from different individuals (five individuals of each species) were fixed in FAA (formaldehyde, acetic acid, 50\% ethanol, 1:1:18 v/v) for $24 \mathrm{~h}$ (JOHANSEN, 1940) and preserved in 70\% ethanol. The samples were dehydrated in an ethanol series and embedded in Historesin ${ }^{\circledR}$ Leica (GERRITS; SMID, 1983). Transverse and longitudinal sections of 5-7 $\mu \mathrm{m}$ thickness were obtained with a rotary microtome and stained with $0.05 \%$ toluidine blue in acetate buffer $(\mathrm{pH} 4.7)$ (O'BRIEN et al., 1964). All slides were temporarily mounted in water. The images were captured with a digital camera (Olympus DP71) coupled to a light microscope (Olympus BX51). Histochemical assays for starch (BERLYN; MIKSCHE, 1976) and total lipids (PEARSE, 1980) were performed using Lugol and Sudan black B, respectively.

For micro-morphological analysis, the samples were dehydrated in an ethanol series, dried by the $\mathrm{CO}_{2}$ critical point method, mounted and metalized with gold. The observations and images were obtained by scanning electron microscopy (SEM) using a Jeol JSM 5800 LV at $10 \mathrm{kV}$ with a coupled digital camera. The morphological description of the trichomes was according to Diane et al. (2003) and Metcalfe and Chalk (1979).

\section{Results}

The following descriptions are based on the results of light microscopy and SEM.

\section{Euploca polyphylla and E. procumbens}

The leaf blades of E. polyphylla and E. procumbens have a uniseriate epidermis on both surfaces (Figure 1AB). In paradermic sections, both have curved anticlinal walls (Figure 1C-D). The epidermal cells are slightly rounded and have irregular size in transversal sections (Figure 1A-B). The leaf blades are amphistomatic (Figure 1A-D). The stomata of E. polyphylla are anomocytic (Figure 1C), while those of E. procumbens can be anomocytic and tetracytic (Figure 1D). E. polyphylla has dorsiventral leaves; the palisade parenchyma is single-layered and the spongy parenchyma has 5-7 layers (Figure 1A). E. procumbens has isobilateral leaves with a layer of palisade parenchyma facing each of the sides and 3-4 layers of spongy parenchyma between the palisade parenchyma (Figure 1B). The parenchyma cells of both species accumulate starch in their interior, evidenced by the positive reaction with Lugol (Figure 1E-F). The midribs are plano-convex, and the midrib region follows the pattern of the mesophyll; however, the palisade parenchyma is only on the upper surface (Figure $1 \mathrm{G}-\mathrm{H})$. E. polyphylla has a starch sheath in the midrib and lateral bundles (C4 photosynthesis) (Figure 1A, E and $\mathrm{G}$ ), while in E. procumbens there are no chloroplasts in the sheath (C3 photosynthesis) (Figure 1B, F and $\mathrm{G}$ ).

Unicellular non-glandular, simple and tapered trichomes were found in the two species (Figure 2A-F) on both surfaces. The abaxial surface of E. polyphylla has a homogeneous distribution of trichomes (Figure 2A), while the adaxial surface has trichomes only in the central region (Figure 2B). The trichomes of $E$. polyphylla are relatively short $(90-250 \mu \mathrm{m})$, appressed to the leaf surface and have protuberances on the surface, and the adjacent epidermal cells form a high base (Figure 2C-D). In E. procumbens, the trichomes are long $(400-500 \mu \mathrm{m})$, curved on the surface, but not appressed or with micropapillae on the surface (Figure 2E-F). The adjacent epidermal cells also form a high base around the trichomes (Figure 2F). The density of the trichomes is more pronounced in E. procumbens with homogeneous distribution on the adaxial and abaxial surfaces (Figure 2E). 
FIGURE 1: General aspects of the leaf blade of Euploca polyphylla (A, C, E and G) and E. procumbens (B, D, F and H). A and B: leaf blade in cross section. $\mathrm{C}$ and $\mathrm{D}$ : stomata and cell wall of the upper surface in paradermic sections. $\mathrm{E}$ and $\mathrm{F}$ : positive reaction to Lugol, demonstrating the presence of starch. G and H: midrib in cross section. Abbreviations: St, stoma; SS, starch sheath; Xy, xylem; Ph, phloem. Scales: $25 \mu \mathrm{m}$ (C-D), $50 \mu \mathrm{m}$ (A-B, E-H).
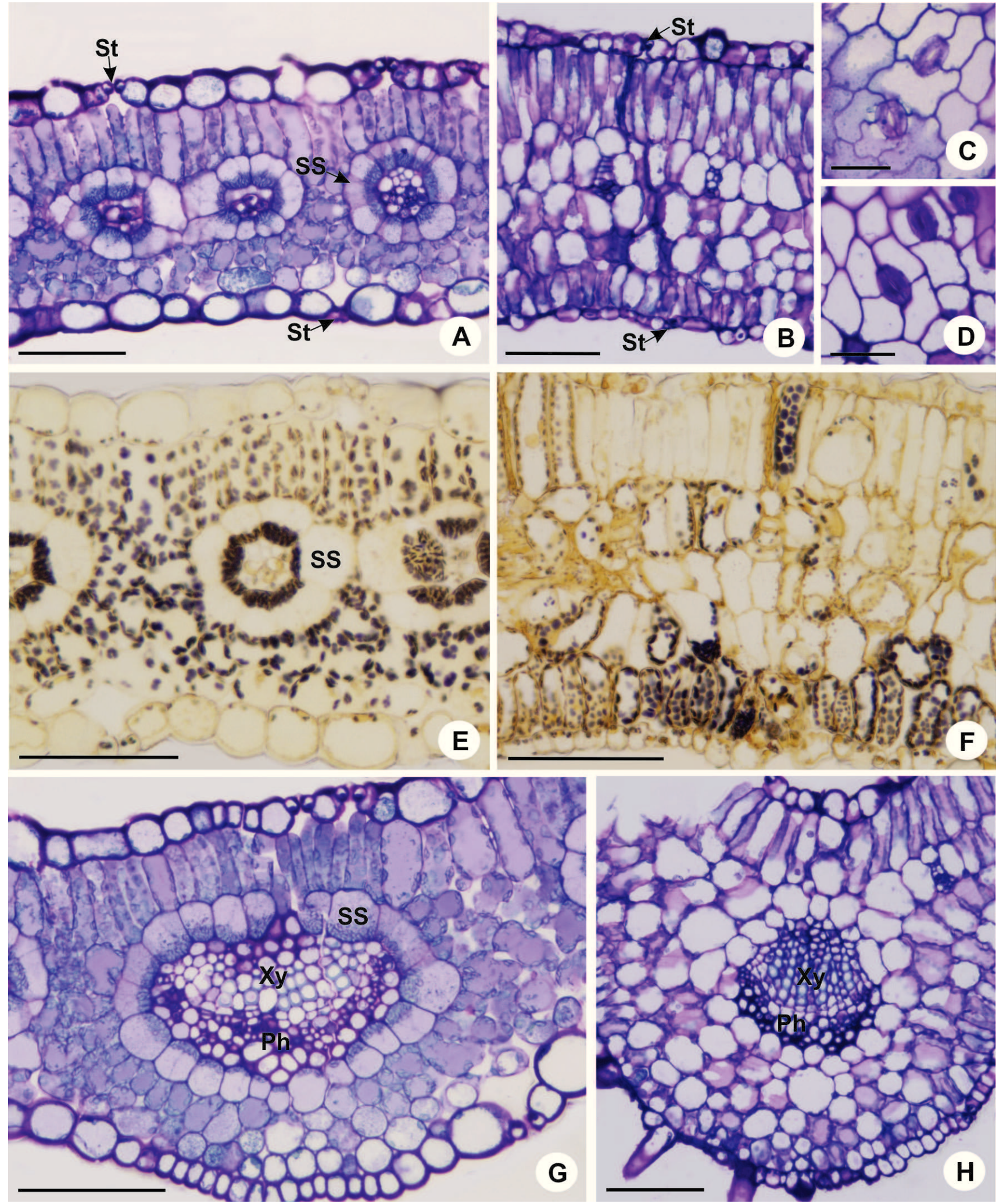
FIGURE 2: Non-glandular trichomes of E. polyphylla (A-D) and E. procumbens (E-F). A: distribution of the trichomes on the abaxial surface. B: adaxial surface with trichomes concentrated in the central region of the leaf blade. C and D: trichome appressed with protuberances (arrow) on adaxial surface. E: distribution of the trichomes on the abaxial surface. F: trichomes not appressed on adaxial surface with micropapillae (arrow). Scales: $20 \mu \mathrm{m}(\mathrm{C}-\mathrm{D}, \mathrm{F}), 100 \mu \mathrm{m}$ (A), $200 \mu \mathrm{m}(\mathrm{B}$ and E).
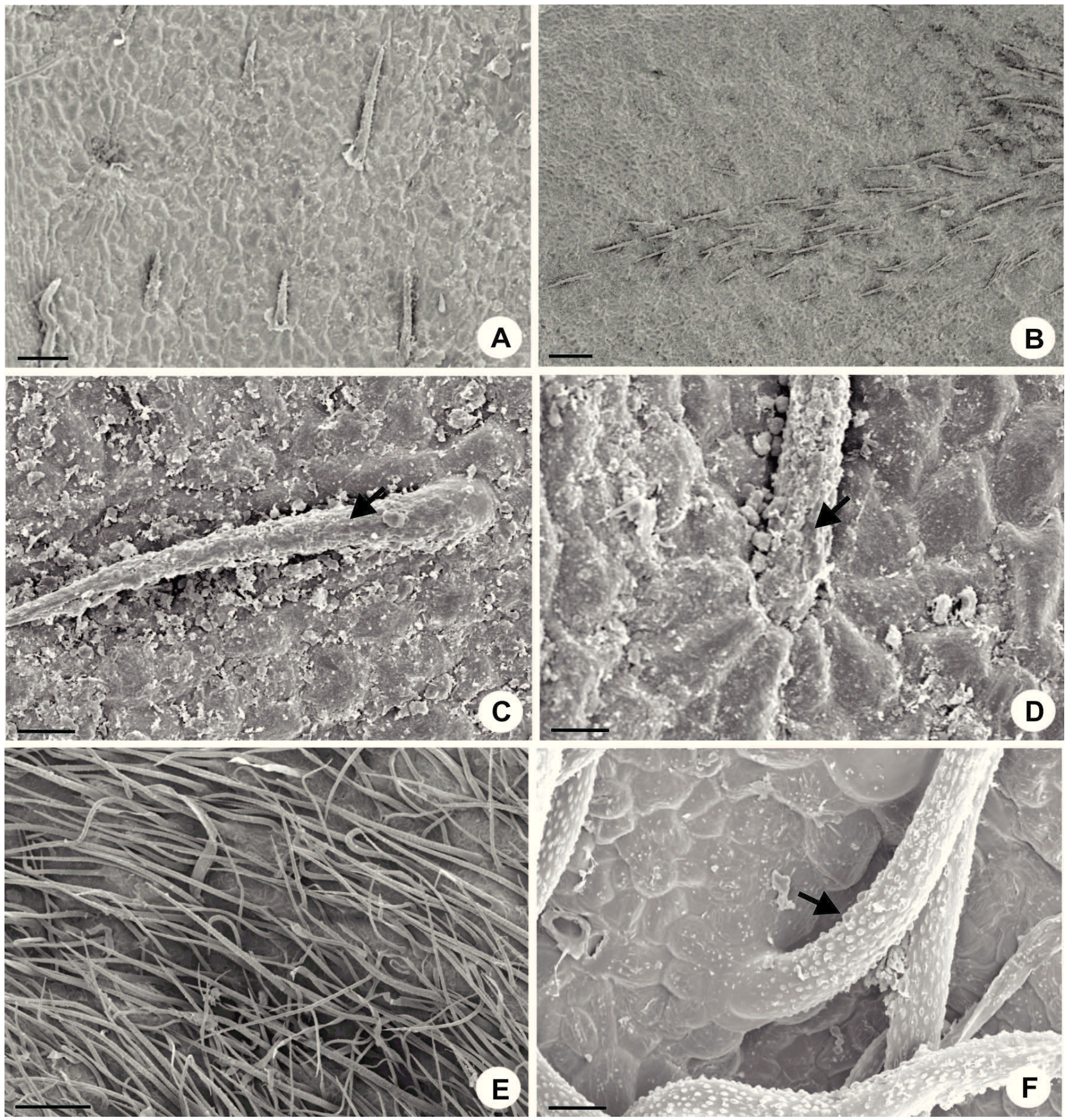

Heliotropium angiospermum and $H_{*}$ curassavicum

H. angiospermum and $H$. curassavicum have a uniseriate epidermis with sinuous anticlinal walls on both surfaces (Figure 3A-C). The epidermal cells are slightly rounded and have irregular size in transversal sections, and they are more elongated vertically in $H$. curassavicum (Figure 3 A-B). H. angiospermum has a hypostomatic blade (Figure $3 \mathrm{~A}$ ) and $H$. curassavicum an 
amphistomatic blade (Figure 3B), both with anomocytic stomata (Figure 3C). H. angiospermum has dorsiventral leaves, the palisade parenchyma is single-layered and the spongy parenchyma has 3-6 layers (Figure 3A). $H$. curassavicum has isobilateral leaves with the palisade parenchyma showing 3-4 layers and parenchyma cells (3-5 layers) in the central region of the blade, not characterized as spongy parenchyma (Figure 3B). Lugol tests were negative for both species. Lithocysts can be seen (Figure 3A-B and D). Collateral vascular bundles are present in the two species (Figures 3E-F and 4B); the midrib of $H$. angiospermum is convex-concave and the cortical region is composed exclusively of parenchyma cells (Figure 3E). The lateral bundles have a sheath of parenchyma cells that stains purple with toluidine blue, (Figure 3F); histochemical tests with Sudan black $B$ indicated the production of lipids (Figure 4A). The midrib of $H$. curassavicum is plano-convex and the midrib region follows the pattern of the mesophyll (Figure 3B).

FIGURE 3: General aspects of the leaf blade of $H$. angiospermum (A, C, E and F) and H. curassavicum (B and D). A and B: leaf blade cross section. C: sinuous walls and anomocytic stomata on the adaxial surface. D: lithocyst in epidermis. E: midrib with collateral vascular bundle and cortical region composed of parenchyma cells. F: lateral bundle with sheath of parenchyma cells. Abbreviations: St, stoma; Li, lithocyst; Xy, xylem; Ph, phloem; SS, sheath. Scales: $20 \mu \mathrm{m}$ (D and F), $50 \mu \mathrm{m}$ (A-B), 100 $\mu \mathrm{m}(\mathrm{E}), 200 \mu \mathrm{m}(\mathrm{C})$.
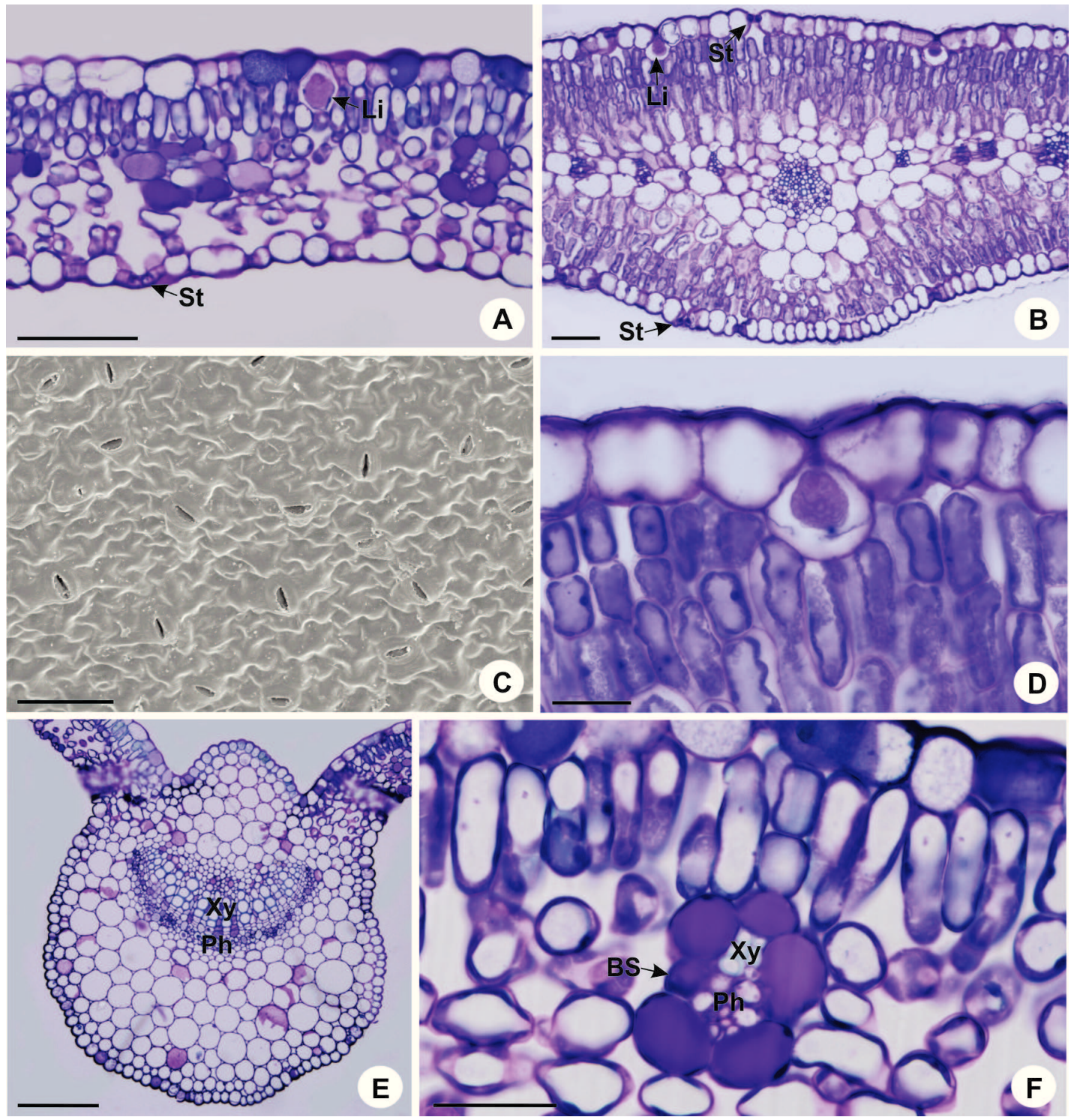
FIGURE 4: General aspects of the leaf anatomy of $H$. angiospermum (A, C, D) and H. curassavicum L. (B). A: positive staining with Sudan black B in the sheath cells. B: midrib showing side organization. C: non-glandular trichome detail around the midrib with micropapillae on the abaxial surface. D: glandular trichomes on the abaxial surface consisting of peduncle and secretory portion (arrows). Abbreviations: Xy, xylem; Ph, phloem. Scales: $20 \mu \mathrm{m}$ (A), $30 \mu \mathrm{m}$ (C), $50 \mu \mathrm{m}$ (B), $100 \mu \mathrm{m}$ (D).
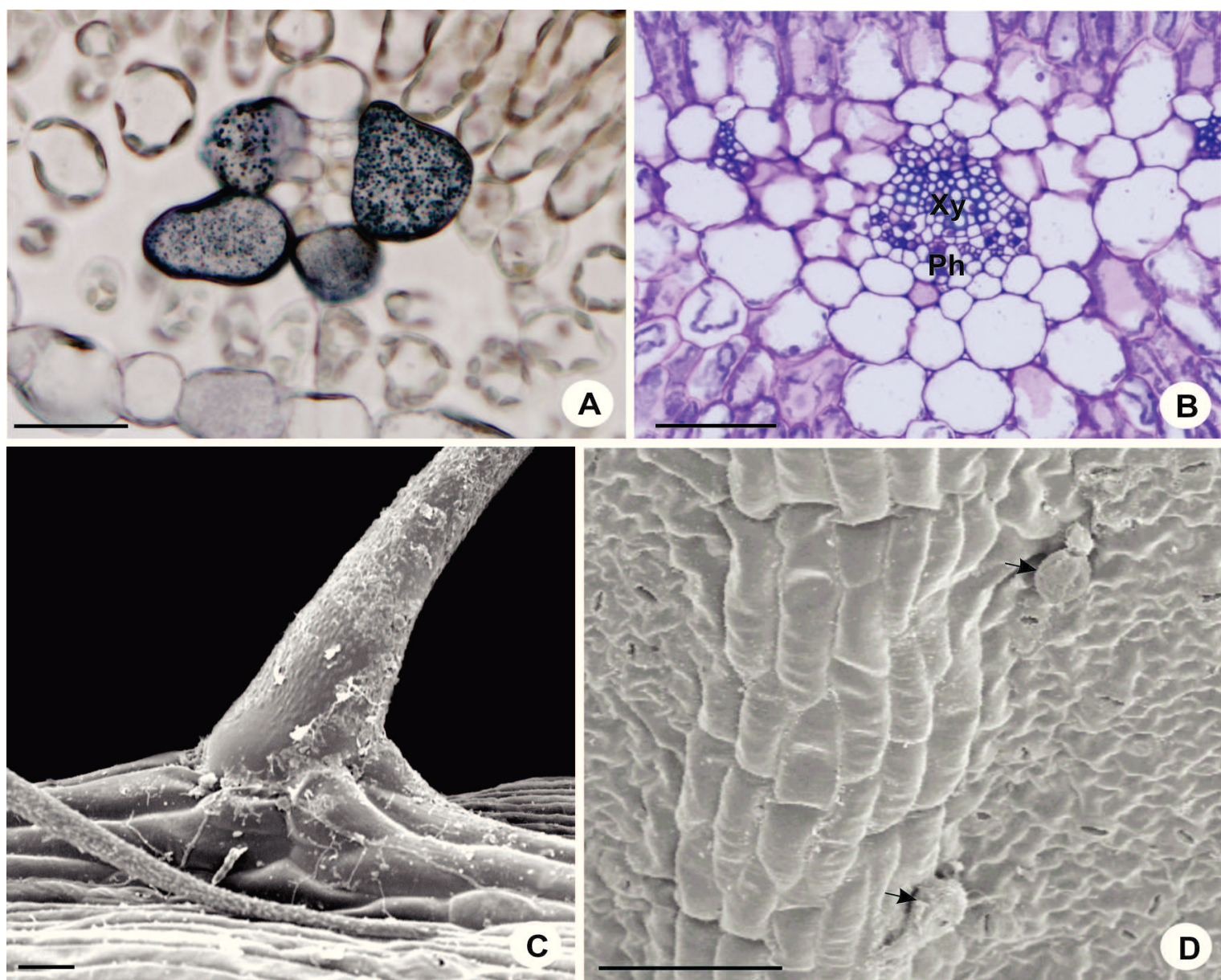

The leaf surface of $H$. curassavicum is glabrous on both surfaces, while $H$. angiospermum has nonglandular, simple, tapered trichomes, located only on the main vein on both sides. The trichomes are long (540$600 \mu \mathrm{m})$, not appressed and with small micropapillae on the surface, and the adjacent epidermal cells form a high base around the trichome (Figure 4C). In the same species, we also observed glandular trichomes consisting of peduncle and secretory portion (Figure 4D).

\section{Myriopus rubicundus and M. salzmannii}

Myriopus rubicundus and M. salzmannii have a uniseriate epidermis with curved walls and anomocytic stomata on both surfaces (Figure 5A-C), and they have hypostomatic leaves (Figure 5A-B). The epidermis of
M. salzmannii is sinuous in paradermic sections (Figure $5 \mathrm{~B})$. The epidermal cells are slightly rounded and are irregular in size in transversal sections (Figure $5 \mathrm{~A}-\mathrm{B}$ ), and the stomata are elevated in relation to neighboring cells (Figure 5D). Both have dorsiventral mesophyll containing one layer of palisade parenchyma; the spongy parenchyma in M. rubicundus contains 4-5 layers, and in M. salzmannii, there are 6-7 layers (Figure 5A-B). Collateral vascular bundles are found in both species (Figure 5E-F) and lateral bundles exhibit a parenchyma sheath (Figure 5A-B). The midrib of M. rubicundus is convex-concave (Figure 5E), and the cortical region displays angular collenchyma (Figure 6A). In $M$. salzmannii, the vascular bundle of the midrib forms a semi-arc, open at the top end (Figure 5F), and the cortical region has annular collenchyma (Figure 6B). 
FIGURE 5: General aspects of the leaf anatomy of $M$. rubicundus (A, C and E) and $M$. salzmannii (B, D and F). A and B: leaf blade cross section. C: curved cell wall and anomocytic stomata on the abaxial surface. D: high stoma above the level of the epidermis. E and F: midrib in cross section. Abbreviations: BS, vascular sheath; St, stoma; Xy, xylem; Ph, phloem. Scales: $20 \mu \mathrm{m}$ (C-D), 40 $\mu \mathrm{m}(\mathrm{A}), 50 \mu \mathrm{m}(\mathrm{B}), 100 \mu \mathrm{m}(\mathrm{E}-\mathrm{F})$.
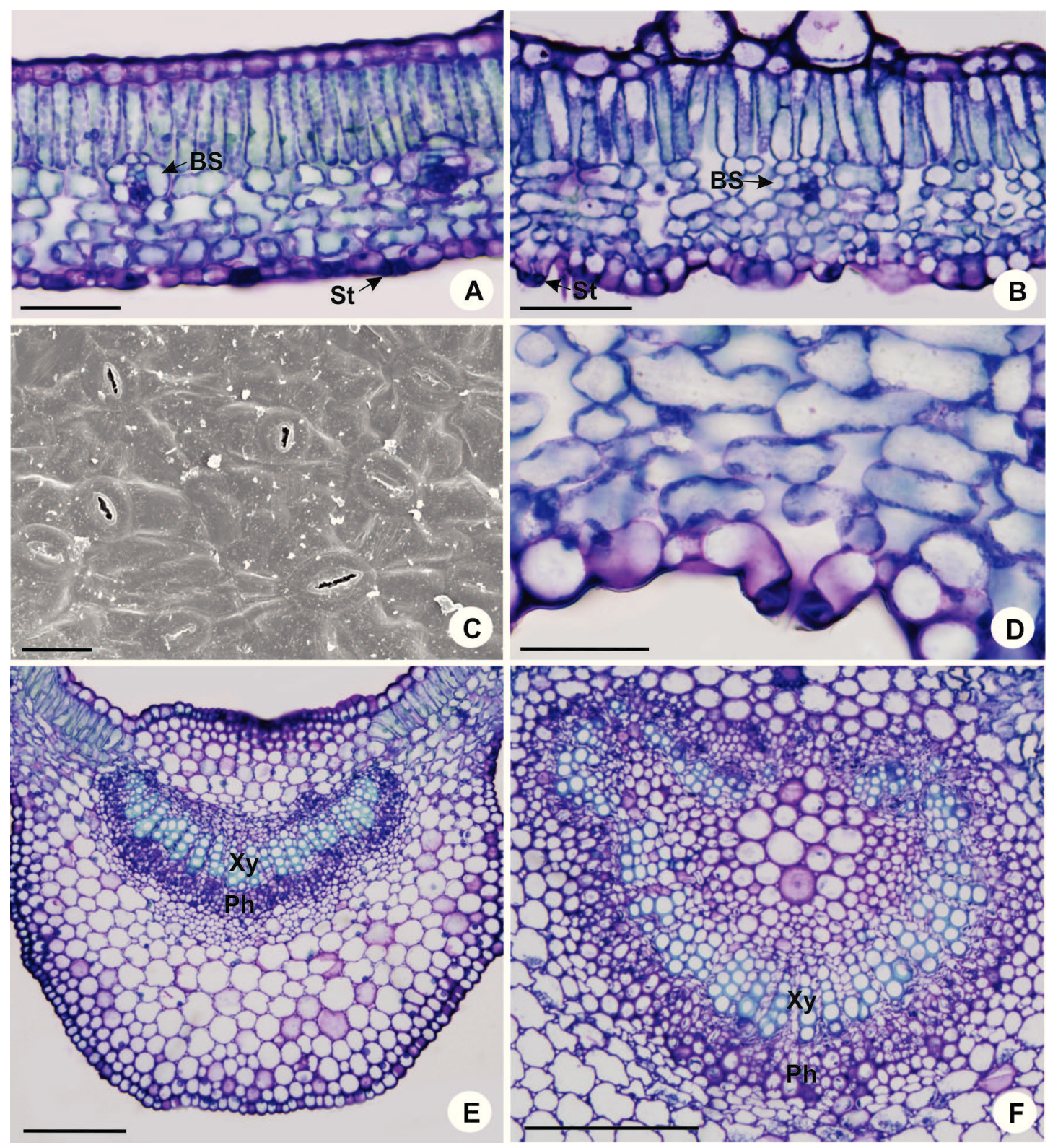

Unicellular, non-glandular, simple and tapered trichomes are distinguished. The first one is distributed trichomes are present in the two species on both surfaces (Figures $6 \mathrm{C}-\mathrm{F}$ and $7 \mathrm{~A}-\mathrm{C}$ ). The trichomes of $M$. rubicundus are quite variable in size (280-550 $\mu \mathrm{m})$ and appressed (Figure 6C-D), and they have a rough surface (Figure 6D), in addition to possessing cystoliths at their base (Figure 6E). In M. salzmannii, the density of the trichomes is more pronounced on the abaxial surface (Figures 6F and 7A), and two types of on both surfaces (Figures $6 \mathrm{~F}$ and $7 \mathrm{~A}$ ), has a bulbous base, is erect, measures $100-500 \mu \mathrm{m}$ and has a smooth surface (Figure 7B). The second type, found in a smaller number, is quite similar to the trichomes described in $E$. procumbens. It is long $(400-500 \mu \mathrm{m})$, with the surface covered by micropapillae, curved in relation to the leaf surface and distributed on the abaxial surface, primarily on the main vein (Figure 7C). 
FIGURE 6: General aspects of the leaf anatomy of M. rubicundus (A, C-E) and M. salzmannii (B and F). A and B: cross section of the midrib, displaying the cortical region. $\mathrm{C}$ : trichomes on the adaxial surface. F: upright, non-glandular trichome of bulbous base on the adaxial surface. D: non- glandular trichome appressed to the adaxial surface. E: cells that form the basis of the nonglandular trichome displaying cystoliths in their interior. F: trichomes of bulbous base on the adaxial surface. Scales: $20 \mu \mathrm{m}$ (E), $40 \mu \mathrm{m}$ (A-B), $100 \mu \mathrm{m}$ (D), $200 \mu \mathrm{m}$ (F), $300 \mu \mathrm{m}$ (C).
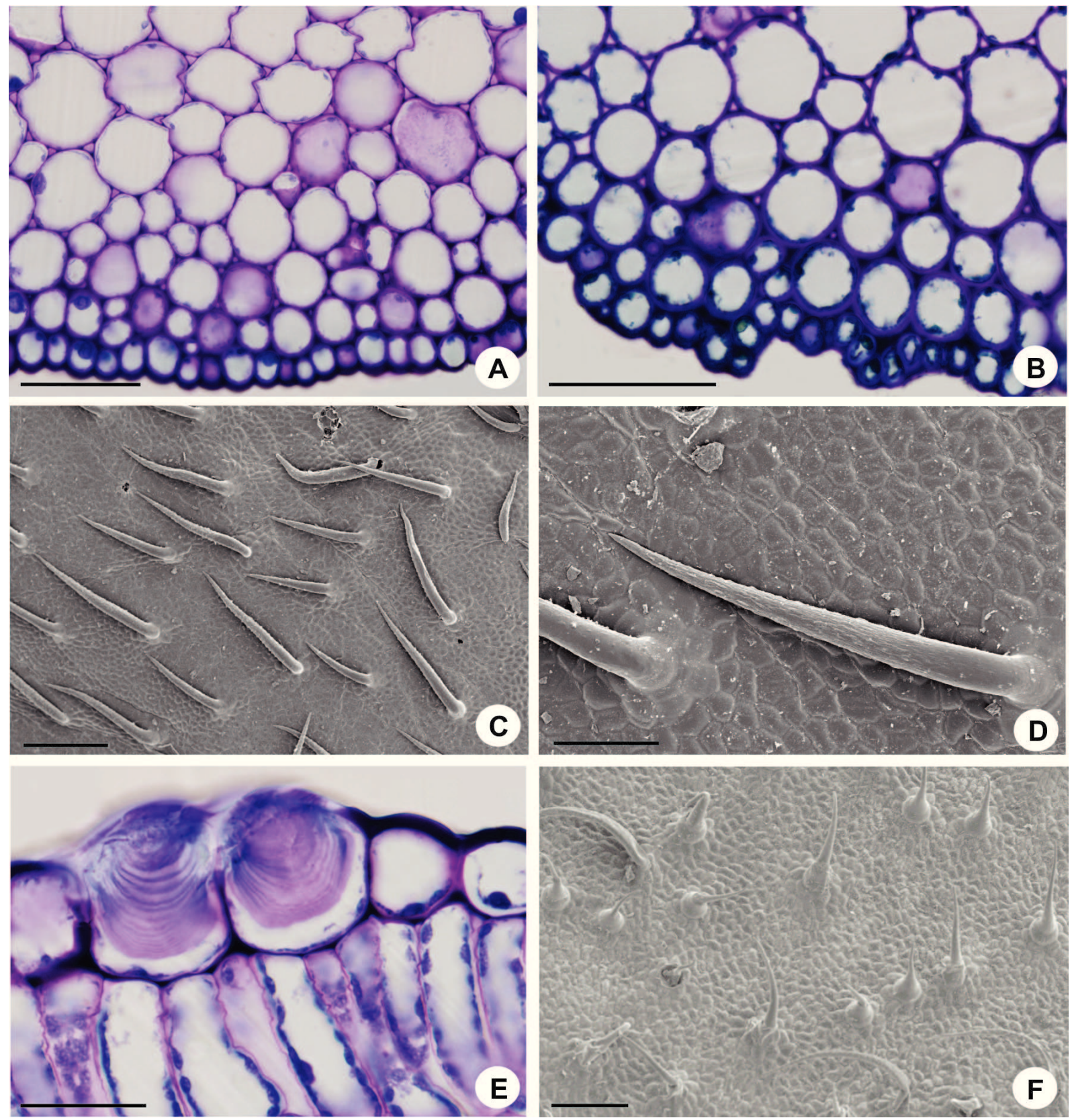

Among the species studied, we observed four types of trichomes, all simple and tapered: type 1 - appressed, with micropapillae on the surface, without cystoliths in the cells of the trichome base; type 2 - curved, with micropapillae on the surface and the adjacent epidermal

cells forming a high base; type 3 - appressed, with micropapillae on the surface and with cystoliths in the epidermal cells; type 4 - upright, bulbous and smooth surface. In Table 1, we summarize the main features found in the species studied. 
FIGURE 7: General aspects of the leaf anatomy of $M$. salzmannii. A: abaxial surface with non-glandular trichomes. B: upright, non-glandular trichome of bulbous base on the adaxial surface. C: non-glandular trichome, simple and tapered on the midrib. Scales: $30 \mu \mathrm{m}$ (B), $100 \mu \mathrm{m}$ (C), $200 \mu \mathrm{m}$ (A).
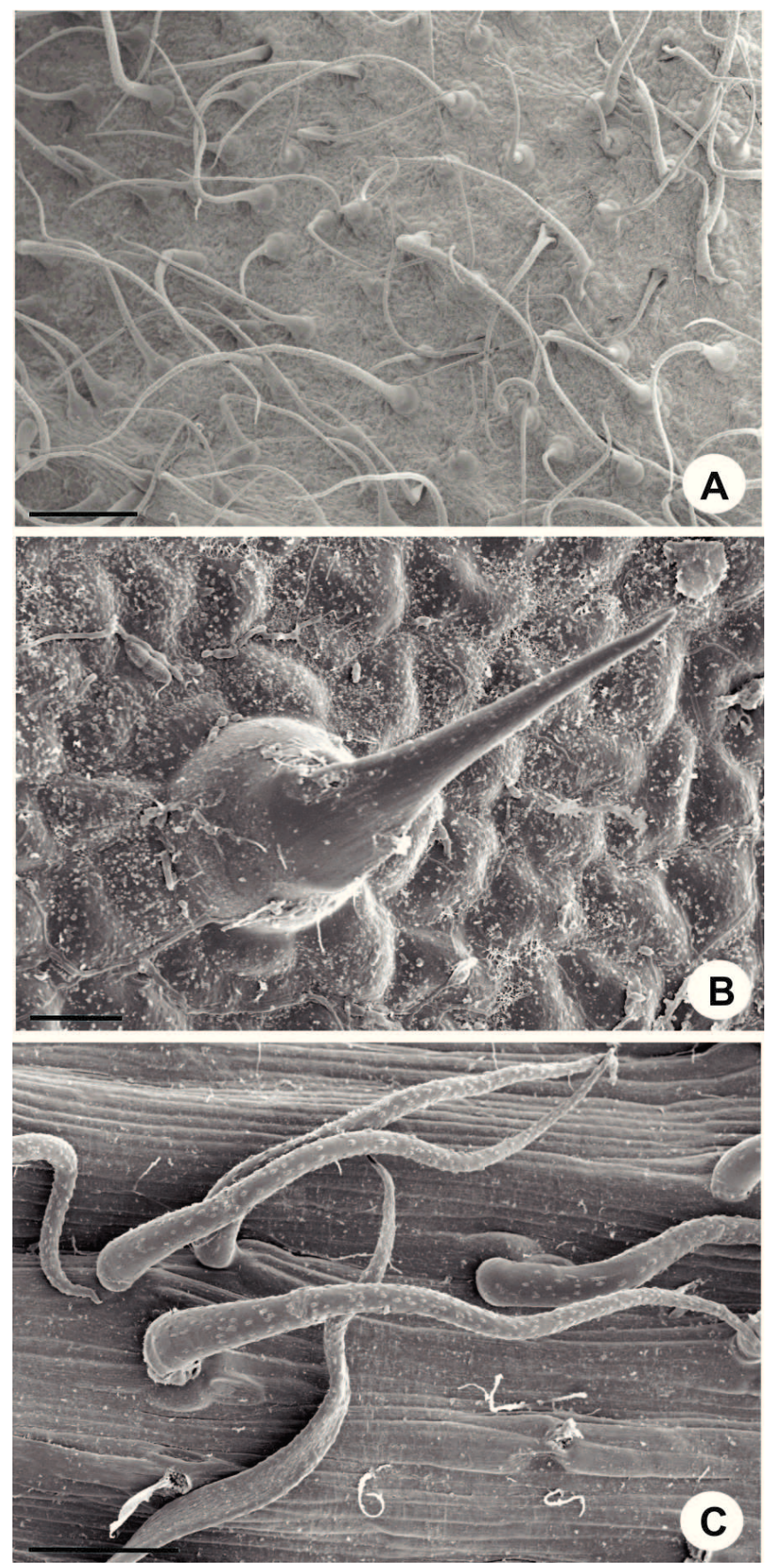

TABLE 1: Summary of the anatomical features of the leaf blade of the species studied.

\begin{tabular}{|c|c|c|c|c|c|c|}
\hline Features/Species & $E 1$ & $E 2$ & $H 1$ & $\mathrm{H} 2$ & $M 1$ & $M 2$ \\
\hline - Epidermis & Uni & Uni & Uni & Uni & Uni & Uni \\
\hline - Anticlinal wall & Cur & Cur & Sin & Sin & Cur & Cur \\
\hline - Stomatal distribution & Amp & Amp & Нyр & Amp & Hyp & Нyр \\
\hline -Type(s) of stoma(ta) & Ano & $\begin{array}{c}\text { Ano/ } \\
\text { Tet }\end{array}$ & Ano & Ano & Ano & Ano \\
\hline - Mesophyll & Dor & Iso & Dor & Iso & Dor & Dor \\
\hline - Reserve substance & Sta & Sta & Abs & Abs & Abs & Abs \\
\hline - Midrib & $\mathrm{PC}$ & $\begin{array}{l}\mathrm{PC} / \\
\mathrm{Sta}\end{array}$ & $\mathrm{CC}$ & PC & $\mathrm{CC}$ & SA \\
\hline - Lateral vein & PS & LS & LS & PS & PS & PS \\
\hline - Lithocysts & Abs & Abs & Pre & Pre & Abs & Abs \\
\hline - Glandular trichomes & Abs & Abs & Pre & Abs & Abs & Abs \\
\hline $\begin{array}{l}\text { - Types of non-glandular } \\
\text { trichomes }\end{array}$ & $\begin{array}{c}\text { Type } \\
1\end{array}$ & $\begin{array}{c}\text { Type } \\
2\end{array}$ & $\begin{array}{c}\text { Type } \\
2\end{array}$ & Abs & $\begin{array}{c}\text { Type } \\
3\end{array}$ & $\begin{array}{c}\text { Types } \\
2 / 4\end{array}$ \\
\hline $\begin{array}{l}\text { - Distribution of non- } \\
\text { glandular trichomes }\end{array}$ & $\mathrm{Ad}$ & $\begin{array}{l}\mathrm{Ad} / \\
\mathrm{Ab}\end{array}$ & $\begin{array}{l}\mathrm{Ad} / \\
\mathrm{Ab}\end{array}$ & $\mathrm{Ab}$ & $\begin{array}{l}\mathrm{Ad} / \\
\mathrm{Ab}\end{array}$ & $\begin{array}{l}\mathrm{Ad} / \\
\mathrm{Ab}\end{array}$ \\
\hline
\end{tabular}

* Abbreviations: E1 - E. polyphylla; E2 - E. procumbens; $H 1-H$. angiospermum; $H 2$ - H. curassavicum; $M 1-M$. rubicundus; M2 - M. salzmannii; Uni - uniseriate; Cur - curved; Sin - sinuous; Amp - amphistomatic; Hyp - hypostomatic; Ano - anomocytic; Tet - tetracytic; Dor - dorsiventral; Iso - isobilateral; Sta - starch; Abs - absent; PC - plano-convex; CC - convex-concave; SA - semiarc; PS - parenchyma sheath; LS - lipid sheath; Pre - present; Ad - adaxial surface; $\mathrm{Ab}$ - abaxial surface.

\section{Discussion}

This study showed that there was variation in the leaf anatomy of the species examined. However, certain features were present in all of them and are typical of the Heliotropiaceae. The presence of crystals (lithocysts) and non-glandular trichomes are important structures for species of the family (METCALFE; CHALK, 1983).

Non-glandular trichomes are often used in the separation of Heliotropiaceae species, extensively described in the work of Diane et al. (2003). The morphological variation of trichomes is broadly discussed as a useful feature for identifying species in several families of Angiosperms (WERKER, 2000), including Heliotropiaceae (METCALFE; CHALK, 1983; DASTI et al., 2003).

Variations in length, curvature and presence/ absence of cystoliths occur in the trichomes of different species of the same genus, or between species belonging to different genera (METCALFE; CHALK, 1983). For 
Heliotropiaceae, Diane et al. (2003) described seven types of non-glandular trichomes. In this study, we found three types of non-glandular trichomes fitting the descriptions given by Diane et al. (2003): unicellular, unbranched trichomes with rough surface and adjacent epidermal cells forming a high base (type 1); multicellular complex - adjacent epidermal cells containing cystoliths (type 3); and unicellular, unbranched trichomes with bulbous base (type 4). Type 2 (curved, with micropapillae on the surface and adjacent epidermal cells forming a high base) was not described in the work of Diane et al. (2003). In their work, the trichomes with adjacent epidermal cells forming a high base are always appressed, whereas the type 2 is curved in relation to the leaf surface.

Crystals also have taxonomic value in the family (METCALFE; CHALK, 1983; DIANE et al., 2003). According to Diane et al. (2003), crystals are often found in the species of the genera Tournefortia (including Myriopus) and Heliotropium. In this study, crystals were reported in the species of Heliotropium (in the lithocysts) and also in the cells of the non-glandular trichome base of M. rubicundus. Cystoliths in the basal part of the trichomes are common in representatives of the family, and sometimes in the epidermal cells adjacent to the trichomes (METCALFE; CHALK, 1983). The lithocysts observed in the two species of the genus Heliotropium are considered by Diane et al. (2003) as reduced unicellular trichomes. However, to confirm such a hypothesis, an in-depth study is required aimed at reconstructing the evolutionary history of trichome morphology in the family.

The mesophyll showed great diversity between the species examined, ranging from isobilateral to dorsiventral in a single genus. Therefore, it should not be used as a diagnostic character between species of different genera. The same is true for characteristics such as size and shape of epidermal cells and type of stomata.

Overall, the leaf anatomy of $M$. salzmannii described here corresponds to the observations made by Diane et al. (2003) for the same species. However, differing from the data described in the above cited work, the leaf of M. salzmannii in the Caatinga environments was hypostomatic, while the specimen examined by
Diane et al. (2003) was amphistomatic. The same occurs in $H$. angiospermum, described by Diane et al. (2003) as amphistomatic; in our study, leaves were found to be hypostomatic. According to Kundu and Tigerstedt (1998), hypostomatic leaves are typical of xeric environments, which allow great water savings by reducing the rate of transpiration. Another different aspect was shown in relation to the types of trichomes of M. salzmannii: Diane et al. (2003) described only type 2 trichomes, and in the present investigation, we also found non-glandular trichomes of bulbous base.

In relation to Euploca, we also found differences in relation to what is described in the literature. In this study, we found only one type of non-glandular trichome in E. procumbens, i.e., curved over the surface, not appressed and with micropapillae. Diane et al. (2003) described two types of trichomes for this species: (1) trichomes with micropapillae on the surface and (2) multicellular complex of lithocysts and slender trichome with the base at the level of the epidermis. This feature may be related to the general environment of the species (Caatinga).

The leaf anatomy of $H$. curassavicum was in accordance with that described by Diane et al. (2003). However, the authors stated that the species had druses in the mesophyll, structures not found in the present study. The number and size of the crystals vary in different periods of the year and also according to the availability of limestone material in the soil (METCALFE; CHALK, 1983), which explains their absence in this work.

Among the species belonging to the genera studied, we found characters with potential diagnostic value. The main feature that differentiates $E$. procumbens from $E$. polyphylla is the Kranz anatomy present in the latter, which was already observed in the work of Muhaidat et al. (2011). In addition, the type and distribution of the trichomes are also important. The main difference between $H$. curassavicum and $H$. angiospermum is the absence of trichomes in the former, while the latter displays non-glandular and glandular trichomes. The species M. salzmannii and E. procumbens differ anatomically primarily by the types of trichomes they have. 
The results obtained can assist in identifying the leaf features of Heliotropiaceae species found in the Caatinga. The anatomical description of M. rubicundus is presented for the first time. Several features were different in relation to the studies already carried out for the same species, for example, the distribution of the stomata in M. salzmannii and $H$. angiospermum, which may be related to environmental factors, since the leaf blade is the structure that changes the most in response to environmental changes (ELIAS et al., 2003).

Because of the great importance of the morphology of trichomes in Heliotropiaceae, we suggest a study encompassing a greater number of species of this family, also including the genus Ixorhea Fenzl, in which species are monospecific and endemic to Argentina. The overall aim would be to determine the types of trichomes and their use in phylogenetic approaches regarding this family.

\section{Acknowledgments}

We thank the Electron Microscopy Laboratory of the State University of Campinas (UNICAMP), Plant Anatomy Laboratory of the State University of Campinas and Botanical Laboratory of the State University of Paraíba (UEPB) for the use of the equipment. J.I.M. Melo thanks the National Council for Scientific and Technological Development (CNPq) for the Research Productivity Scholarship (PQ-2 Process number 302751/2012-2). Dr. A. Leyva helped with English editing of the manuscript.

\section{References}

BERLYN, G. P.; MIKSCHE, J. P. Botanical microtechnique and cytochemistry. Iowa: The Yowa State University Press, 1976. 336 p. CAVAlHEIRO, L.; RANGA, N. T.; FURLAN, A. Tournefortia L. (Boraginaceae): espécies do Brasil extra-amazônico. Hoehnea, São Paulo, v. 38, n. 2, p. 221-241, 2011.

DASTI, A. A.; BOKHARI, T. Z.; MALIK, S. A.; AKHTAR, R. Epidermal morphology in some members of family Boraginaceae in Baluschistan. Asian Journal of Plant Sciences, Lasani, v. 2, n. 1, p. 42-47, 2003.

DIANE, N.; FÖRTHER, H.; HILGER, H. H. A systematic analysis of Heliotropium, Tournefortia, and allied taxa of the Heliotropiaceae (Boraginales) based on ITS1 sequences and morphological data.
American Journal of Botany, Saint Louis, v. 89, n. 2, p. 287-295, 2002.

DIANE, N.; FÖRTHER, H.; HILGER, H. H.; WEIGEND, M. Heliotropiaceae. The families and genera of vascular plants. VI. Flowering plants. Berlin: Springer, 2004. 489 p.

DIANE, N.; JACOB, C.; HILGER, H. H. Leaf anatomy and foliar trichomes in Heliotropiaceae and their systematic relevance. Flora, Jena, v. 198, n. 6, p. 468-485, 2003.

ELIAS, S. R. M.; ASSIS, R. M; STACCIARINI-SERAPHIN, E.; REZENDE, M. H. Anatomia foliar em plantas jovens de Solanum lycocarpum A. St.-Hil. (Solanaceae). Revista Brasileira de Botânica, São Paulo, v. 26, n. 2, p. 169-174, 2003.

FARIÑA, A.; ARRIECHE, D.; BOADA-SUCRE, A.; VELÁZQUEZ, D. Anatomía comparada de la lámina foliar de especies de Heliotropium L. (Boraginaceae) presentes em Venezuela. Interciencia, Caracas, v. 28, n. 2, p. 68-74, 2003.

GERRITS, P. O.; SMID, L. A new, less toxic polymerization system for the embedding of soft tissues in glycol methacrylate and subsequent preparing of serial sections. Journal of Microscopy, Oxford, v. 132, p. 81-85, 1983.

GOTTSCHLING, M.; DIANE, N.; HILGER, H. H.; WEIGEND, M. Testing hypotheses on disjunctions present in the primarily woody Boraginales: Ehretiaceae, Cordiaceae, and Heliotropiaceae, inferred from ITS1 sequence data. International Journal of Plant Sciences, Chicago, v. 165, n. 4, p. 123-135, 2004.

IBÁÑEZ, S.; LUEBERT, F.; GÓMEZ, M. Primer registro de Heliotropium amplexicaule (Heliotropiaceae) em Chile. Gayana Botánica, Concepción, v. 68, n. 1, p. 93-96, 2011.

JOHANSEN, D. A. Plant microthechnique. New York: McGraw Hill, 1940. 523 p.

KUNDU, S. K.; TIGERSTEDT, P.M. Variation in net photosynthesis, stomatal characteristics, leaf area and whole plant phytomass production among ten provenances of neem (Azadirachta indica). Tree Physiology, Victoria, v. 19, p. 47-52, 1998.

LUEBERT, F.; BROKAMP, G.; WEN, J.; WEIGEND, M.; HILGER, H. H. Phylogenetic relationships and morphological diversity in Neotropical Heliotropium (Heliotropiaceae). Taxon, Vienna, v. 60, n. 3, p. 663-680, 2011.

MELO, J. I. M.; ALVES, M.; SEMIR, J. Padrões de distribuição geográfica das espécies de Euploca e Heliotropium (Heliotropiaceae) no Brasil. Rodriguésia, Rio de Janeiro, v. 60, n. 4, p. 1025-1036, 2009.

MELO, J. I. M.; ANDRADE, W. M. Boraginaceae s.l. A. Juss. em uma área de Caatinga da ESEC Raso da Catarina, BA, Brasil. Acta Botanica Brasilica, Feira de Santana, v. 21, n. 2, p. 369-378, 2007.

MELO, J. I. M.; SALES, M. F. Boraginaceae A. Juss. na região de Xingó: Alagoas e Sergipe. Hoehnea, São Paulo, v. 32, n. 3, p. 369-380, 2005.

MELO, J. I. M.; SEMIR, J. Taxonomia do gênero Heliotropium L. (Heliotropiaceae) no Brasil. Acta Botanica Brasilica, Feira de Santana, v. 22, n. 3, p. 754-770, 2008.

MELO, J. I. M.; SEMIR, J. Taxonomia do gênero Euploca Nutt. (Heliotropiaceae) no Brasil. Acta Botanica Brasilica, Feira de Santana, v. 24, n. 1, p. 111-132, 2010.

METCALFE, C. R.; CHALK, L. Anatomy of the dicotyledons. Vol. 1. Oxford: Clarendon Press, 1979. 276 p. 
METCALFE, C. R.; CHALK, L. Anatomy of the dicotyledons. Vol. 2. Oxford: Clarendon Press, 1983. 330 p.

MUHAIDAT, R.; SAGE, T. L.; FROHLICH, M. W.; DENGLER, N. G.; SAGE, R. F. Characterization of C3-C4 intermediate species in the genus Heliotropium L. (Boraginaceae): anatomy, ultrastructure and enzyme activity. Plant, Cell \& Environment, Oxford, v. 34, p. 1723-1736, 2011.

O'BRIEN, T. P.; FEDER, N.; MCCULLY, M. E. Polychromatic staining of plant cell walls by toluidine blue O. Protoplasma, Heidelberg, v. 59, p. 368-373, 1964.
PEARSE, A. G. E. Histochemistry theoretical and applied preparative and optical technology. 4. ed. Edinburgh: Churchill Livingston, 1980. $439 \mathrm{p}$.

VIEIRA, D. D.; CONCEIÇÃO, A. S.; MELO, J. I. M.; STAPF, M. N. S. A família Boraginaceae sensu lato na APA Serra Branca/Raso da Catarina, Bahia, Brasil. Rodriguésia, Rio de Janeiro, v. 64, p. 151-168, 2013.

WERKER, E. Trichome diversity and development. Advances in Botanical Research, London, v. 31, p. 1-35, 2000. 